\section{Pro-life actions backfire}

\section{London}

LAST week's support for human embryo research in Britain by an overwhelming 364 votes to 193 in the House of Commons (see Nature 344, 799; 26 April 1990) came as something of a surprise. Most proresearch lobbyists had expected victory, but both they and their 'pro-life' opponents had been predicting a close result in the run-up to the debate (see Nature 344, 691; 19 April 1990). In a second vote, Members of Parliament (MPs) decided by 362 votes to 189 to set up a statutory licensing authority to regulate research on embryos that are 14 days old or less.

Professor Robert Winston, president of PROGRESS, the leading pro-research lobbying group, describes the majorities as "a vote of confidence in the integrity of British science and medicine". He says he perceived a shift in opinion among MPs, in favour of continued research, in the week preceding the vote. The publication of his own group's research paper, describing an in vitro technique to determine the sex of fertilized embryos and thus to screen for sex-linked genetic diseases (Nature 344, 768; 19 April 1990) was a factor, he thinks: the paper illustrated the "genuine benefit" of research.

Winston says the anti-research lobby's campaign undermined its own cause. Frank Cook, a Labour MP who came to the debate with his vote undecided, believed both sides had made misleading

claims, but said "the confusion caused by the pro-lifers is the most obfuscating"

One significantly counterproductive act, according to Christine Lavery of the pro-research Genetic Interest Group, was the decision by the Society for the Protection of Unborn Children (SPUC) to send a life-sized model of a 20 -week-old fetus to all MPs. The move was designed to influence the following day's votes on the upper time limit for abortion, but it backfired: MPs voted for a 24-week maximum rather than the 22 weeks or less which had been predicted. Lavery says the distasteful models also turned "wavering" MPs against SPUC's anti-research arguments. SPUC led the pro-life campaign on both issues.

During the embryo research debate, several MPs argued that accepting research would be the beginning of a "slippery slope". Conservative MP Alan Amos said scientists would soon call for extensions to the 14-day limit. But Winston rejects this claim: scientists and doctors take their moral responsibilities "extremely seriously" he says.

The large pro-research majority will be reflected in the composition of the committee that will now consider the Human Fertilization and Embryology Bill in detail. This should mean that its passage through parliament is not delayed by the addition of "nitpicking" amendments, Winston says.

Peter Aldhous

\section{ABORTION}

\section{The sunny side of the street . . . \\ Munich}

A Swiss entrepreneur has come up with a new solution to one of the major problems of using solar energy - where to put all the solar cells. Hundreds of acres are needed to generate any significant amount of energy, but meadows and mountainsides would be blighted if they were covered with huge, ugly solar arrays.

Thomas Nordmann of Chur has persuaded the Swiss government to try installing solar cells alongside an Alpine highway. The cells, mounted for 880 metres atop a sound baffle, provide 100 kilowatts of power to the local electricity grid.

The cells were installed in late 1989 as the first stage in a large-scale experiment in exploiting unused areas for solar energy generation. During the next phase, already under way, Nordmann's firm, TNC Consulting AG, is installing solar cells along a railway line in Ticino in southern Switzerland.

Nordmann will have completed four test sites by 1996 , after which the Swiss government will decide if it wants to continue the project.

Solar cells installed only in the most advantageous areas, says Nordmann, could ultimately provide 11,000 households with up to 45 megawatts of power at

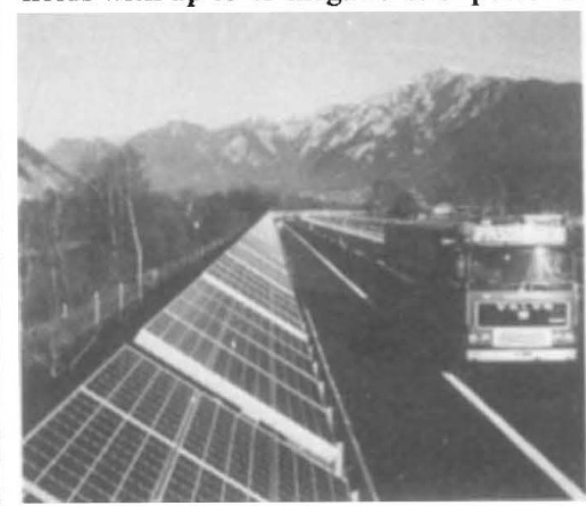

Road move: Part of the half-mile of solar panels alongside an Alpine highway.

peak demand times in winter. If all potential highway sites in Switzerland were used, solar cells could by the year 2000 provide 375 megawatts, as much as a medium-sized conventional power plant.

But the price will have to come down. At present, solar energy from Nordmann's cells costs one Swiss franc (about \$0.68) per kilowatt-hour, which is three to ten times higher than the market price of electricity. By 2000 , Nordmann hopes that solar energy will be competitive with traditional power sources, at least at the daytime hours when demand is at its peak. The costs would come down through economies of scale and technical improvements, he says.

Nordmann has no patent on his idea. Others are free to copy it, he says, "but if it's going to be a poor copy, maybe they had better call us".

Steven Dickman
Peter Coles requires a level of medical support which, the report says, would rarely be available 